$\begin{array}{ll}\text { Research Square } & \begin{array}{l}\text { Preprints are preliminary reports that have not undergone peer review. } \\ \text { They should not be considered conclusive, used to inform clinical practice, } \\ \text { or referenced by the media as validated information. }\end{array}\end{array}$

\title{
Isolated Donor site Tumour Recurrence at Pectoralis Major Myocutaneous Flap in Oral Cavity Squamous Cell Carcinoma - A Rare Case Report and Review of Literature
}

\author{
Prathamesh Chandrapattan \\ SOA IMS and SUM Hospital: Siksha O Anusandhan University Institute of Medical Sciences and SUM Hospital https://orcid.org/0000-0002-6503-3634 \\ Sangram Keshari Panda \\ SOA IMS and SUM Hospital: Siksha O Anusandhan University Institute of Medical Sciences and SUM Hospital https://orcid.org/0000-0002-8771-4158 \\ Pradyumna Kumar Sahoo \\ SOA IMS and SUM Hospital: Siksha O Anusandhan University Institute of Medical Sciences and SUM Hospital \\ Chira Khadanga \\ SOA IMS and SUM Hospital: Siksha O Anusandhan University Institute of Medical Sciences and SUM Hospital \\ Sunil Agrawala ( $\square$ drsunil759@gmail.com) \\ SOA IMS and SUM Hospital: Siksha O Anusandhan University Institute of Medical Sciences and SUM Hospital
}

\section{Case report}

Keywords: PMMC flap, flap donor site tumour recurrence, oral cavity squamous cell carcinoma

Posted Date: September 13th, 2021

DOI: https://doi.org/10.21203/rs.3.rs-871686/v1

License: (c) (i) This work is licensed under a Creative Commons Attribution 4.0 International License. Read Full License 


\section{Abstract}

Background: Pectoralis Major MyoCutaneous (PMMC) flap has been commonly used since decades for plastic reconstruction in oral cavity cancer surgery. However, rarely the PMMC donor site develops tumor recurrence. Management includes surgical resection in unifocal lesion or salvage radical chemoradiotherapy in clinico-radiologically nonmetastatic unresectable disease which results in satisfactory tumor related outcomes.

Case presentation: A 46 year gentleman known case of Squamous Cell Carcinoma left Retromolar Trigone after surgery and adjuvant radiotherapy presented with isolated recurrence at PMMC flap donor vascular pedicle site which was abutting left subclavian vein and so was managed with concurrent chemoradiotherapy with curative intent and is on follow up since 2 years with no evidence of recurrence.

Conclusions: Isolated PMMC flap donor site recurrence in oral cavity squamous cell carcinoma management is complex, with surgical intervention with excision of such lesions in absence of any other deposits is preferable approach. Concurrent CTRT is an alternative option in curative intent when the lesion is not surgically resectable or the patient refuses surgery.

\section{Background}

Head and Neck Squamous Cell Carcinoma (HNSCC) is a major cancer burden not only in India but also in the world. In India, HNSCC accounts for almost 23\% of all cancers in male and $6 \%$ in female, out of which almost $80 \%$ of patients present in late stages (AJCC Stage III-IV B) ${ }^{1}$. Despite the aggressive multimodality therapy, the local and distant failures are approximately $60 \%$ and $40 \%$ respectively ${ }^{2}$. However, the cancers of the oral cavity subsite of HNSCC have a favourable prognosis due to the possibility of complete surgical resectability followed by adjuvant radiotherapy(RT) or chemoradiotherapy(CTRT) based on their histopathology. In order to achieve a good and satisfactory oral cavity functional outcome the postoperative tissue defect usually require some form of tissue transfer to achieve an optimal reconstruction. Although there are several plastic reconstructive surgical options available for oral cavity cancer postoperative surgical defects, the Pectoralis Major Myo-Cutaneous Flap (PMMC) based reconstruction is an well established as well as accepted modality due to ease of raising the flap, predictable blood supply, less time consuming, cost effective and reliability ${ }^{3}$.

However, in spite of the favourable advantages of the PMMC flap, isolated tumor recurrences have been observed in the PMMC donor site ${ }^{4,5}$. The mechanism of seeding of the primary tumor cells to graft donor site is unclear and controversial, violating the principles of tumor surgery by a poor surgical technique and direct transfer of viable tumor cells from the primary site to the donor site or hematogenous transfer of tumour cells have been described as possible causes ${ }^{6}$ In recurrent and/or metastatic HNSCC, the contemporary treatment options are either local therapy (salvage surgery and/or radiotherapy) or systemic therapy (chemotherapy, biological therapy, immunotherapy). Among the above various treatment modalities, local therapy only yields better durable response in comparison with systemic therapy ${ }^{7}$. The below mentioned case described case highlights the successful curative treatment with concurrent chemoradiotherapy in an unresectable isolated unifocal recurrence in the upper anterior chestwall near PMMC donor site in a previously treated oral cavity SCC with review of literature.

\section{Case Report}

A 46 year gentleman is a k/c/o Squamous Cell Carcinoma(SCC) left Retromolar Trigone. He underwent Wide local Excision with segmental mandibulectomy with left upper alveolectomy with left Modified radical neck dissection with PMMC flap reconstruction on 15/06/2015. Final HPR revealed a well differentiated SCC with size $-3 \times 2.5 \times 2 \mathrm{~cm}$, depth of invasion $-4.84 \mathrm{~mm}$, All margins ( $>5 \mathrm{~mm}$ ) were free of tumour with negative LVI and PNI, out of 31 lymph nodes, no node showed tumour metastasis. Following which he received adjuvant External Beam Radiotherapy of 60Gy/30\# from 23/07/15 to 10/09/15 and was on regular follow up.

He developed recurrence at primary site after disease free interval of 3 years and 2 months with on examination had a suspicious node in contralateral neck. Metastatic workup by PET scan was negative for distant metastases and underwent a wide local excision of tumour with tongue flap reconstruction with right MRND and dismantling of PMMC flap on 3/12/18. Final HPR showed moderately differentiated SCC, size $-2.3 \times 1.8 \times 0.9 \mathrm{~cm}$, depth of invasion -4 mm, LVI present, $\mathrm{PNI}$ absent, all margins free, 0/38 lymph nodes positive.

Multidisciplinary tumor board decision was for close observation only. Hence, he was on regular followup till this present episode

After a disease free interval of 11 months on 26/11/2019 patient presented with pain and swelling which was hard and fixed over left upper anterior chest wall corresponding to the site of the vascular pedicle of PMMC flap (Fig. 1A), primary disease site over oral cavity and neck exam was normal, biopsy from the swelling yielded - Metastatic SCC (Fig. 1B). MRI chest showed - Lobulated mass in left infra clavicular region and upper anterior chest wall at caudal aspect of PMMC flap abutting subclavian vein (Fig. 2A-2C). Metastatic workup was done with PETCT which shows no metaststic deposit elsewhere.

Multidisciplinary tumor board decided for salvage radical radiotherapy with concurrent weekly intravenous cisplatin in view of unifocal superficial left upper anterior chestwall recurrence with close abutment of left subclavian vein which precluded for a radical surgery. Hence, he received radical radiotherapy to the gross disease with adequate margins to a dose of $66 \mathrm{~Gy}$ in 33 fractions over 7 weeks with intensity modulated radiotherapy (IMRT) technique in medical linear accelerator along with radiosensitizing concurrent chemotherapy intravenous cisplatin $35 \mathrm{mg} / \mathrm{m} 2 \mathrm{BSA}$ (body surface area)(Fig. 2D). Post-treatment followup after 6 months showed complete clinico-radiological response without any significant late radiotherapy toxicity and is on regular follow up since 2 years.

(Fig. 3A-3B)

\section{Discussion}


Radical surgery with appropriate and optimal reconstruction followed by postoperative adjuvant radiotherapy or chemoradiotherapy is the current established standard of care in oral cavity squamous cell carcinoma. Definitive chemoradiotherapy is an alternate option in unresectable case. Out of several options available for head-neck reconstructions, PMMC flap is commonly used as a primary modality as well as a salvage mechanism after failure of a free vascularized flap since last 40 years due to its ease of raising the flap, predictable blood supply, less time consuming, cost effective and reliability ${ }^{2,3}$. The common complications associated with use of PMMC have been described which include flap necrosis, infection, seroma, fistula ${ }^{2}$. The rare complications like rib osteomyelitis, metastasis to donor site of PMMC flap has been described but occur very rarely 4,5 . In PMMC donor site recurrence the underlying cause and mechanism of seeding of the primary tumor to graft donor site is not clear. Although direct contamination by viable tumor cells present on gloves and surgical instruments while performing definitive operation and harvesting autologous graft at the same sitting is most likely, however, it can also be attributed to altered circulation at the healing donor site. Some theoretical and experimental evidence links localization of tumour cells due to surgically induced trauma. Theories supporting this include increased circulating tumor cells occurring during manipulation of primary tumor, damaged endothelium of the microcirculation causing increased adherence of tumor cells, and blood flow or coagulation mechanism alteration in the traumatized graft harvesting site ${ }^{7}$.

After a definitive treatment of HNSCC, recurrence and/or distant metastasis happens in approximately $50 \%$ of the patients over a period of time ${ }^{8}$. These patients obviously have extremely poor prognosis (median overall survival of 6-12 months) ${ }^{9}$. Although the contemporary established treatment methods for recurrent and/or metastatic HNSCC are either local therapy (salvage surgery and/or radiotherapy) or systemic therapy (chemotherapy, biological therapy, immunotherapy), local therapy only yields better durable response in comparison with systemic therapy ${ }^{10}$.

Our patient developed an unifocal superficial solid-cystic fixed tender biopsy proven recurrence at left upper anterior chestwall near PMMC donor scar site resembling with above literature described PMMC donorsite recurrence. In view of clinicoradiologically unifocal biopsy proven recurrence, controlled locoregional disease and good general condition, the institutional multidisciplinary tumor board suggested for a curative intent salvage radical radiotherapy with weekly cisplatin based concurrent chemotherapy over a radical re-do surgery as radiologically the tumor was encasing the subclavian vein. On followup after 6 months of treatment, there was clinico-radiologically complete response. Now he is on regular follow up for last 2 years

Table 14,5,11,12,13,14 highlights other similar cases described in literature where oral cavity squamous cell carcinoma recurred over the anterior chest wall at PMMC donor site. The pattern of recurrence can be two types - one is metastases on PMMC vascular pedicle site $4,5,12$, which can be attributed mainly to lymphovascular spread of tumour cells occurring through the PMMC flap itself, and second is metastases over sites other than vascular pedicle site - either anterior chest wall $5,11,13$, or PMMC flap muscle ${ }^{14}$ which can be due to direct transfer of tumour cells as contamination during surgery highlighting importance to change of gloves, thorough wash of surgical site and cleaning of instruments or to use a different set to avoid cross contamination during surgery.

\section{Conclusion}

Management of oral cavity squamous cell carcinoma recurrence in PMMC site is complex and based on primary site disease status, the extent of chest wall involvement and metastases to other distant sites. Surgical intervention with excision of such lesions in absence of any other deposits is preferable approach. Concurrent CTRT is an alternative option in curative intent when the lesion is not surgically resectable or the patient refuses surgery. Palliative approach in cases of multiple sites of metastases and poor general condition of patient.

\section{Abbreviations}

\section{HNSCC}

Head and Neck Squamous Cell Carcinoma, LVI-Lymphovascular Invasion, PMMC - Pectoralis Major MyoCutaneous flap, PNI-Perineural Invasion, SCCSquamous cell carcinoma

\section{Declarations}

Ethics approval and consent to participate: Written informed consent was obtained from the patient for publication of the case report and accompanying images

Consent for publication: Written informed consent was taken from the patient for publication

Availability of data and materials: All data generated or analysed during this study are included in this published article

Competing interests: The authors declare that they have no competing interests

Funding: None

Authors' contributions:

Prathamesh Chandrapattan- collected and analysed the data of patient and was a part of tumour board in deciding the further course of management of patient and was provided major contribution in writing and editing the manuscript

Sangram Keshari Panda- contributed significantly in writing case report and discussion section on the manuscript

Pradyumna Kumar Sahoo-contributed in editing the table and collecting relevant data related to similar cases and was a part of tumour board in decision making of further line of management 
Chira Khadanga - planned and executed adjuvant definitive CTRT to the patient and helped providing treatment related data for the patient with contribution to discussion section in manuscript

Sunil Agrawala- compiled all data of the patient. Communicated with all the authors and final editing of the article with submission of the article for further correspondence

All authors read and approved the final manuscript

Acknowledgements: Not applicable

\section{References}

1. Al-Sarraf M. Treatment of locally advanced head and neck cancer: historical and critical review. Cancer Control 2002; 9:387-99; PMID:12410178

2. Marur S, Forastiere AA; Head and Neck Cancer: Changing epidemiology, diagnosis and treatment, Mayo Clinic Proc 83, 489-501, 2008

3. Tripathi M, Parshad S, Karwasra RK, Singh V. Pectoralis major myocutaneous flap in head and neck reconstruction: An experience in 100 consecutive cases. National journal of maxillofacial surgery. 2015 Jan;6(1):37

4. Badellino F, Berrino P, Campora E, Canavese G, Galli A, Margarino G, Scala M, Santi PL. Metastatic spread of floor of the mouth squamous cell carcinoma via pectoralis major myocutaneous flap. Journal of surgical oncology. 1988 May;38(1):45-7.

5. Jog M, MacKenzie K, Dempster J. Tumour recurrence at the donor site of the pectoralis major myocutaneous flap with a tumour free index site. Int $\mathrm{J}$ Otorhinolaryngol. 2005;4(1).

6. Kroll SS, Tavollali M et al. Risk of dissemination of cancer to the flap donor sites during immediate reconstructive surgery.Ann Plastic Surg 1994;33,573575

7. Khadanga Chira R, Gajagowni J: latrogenic implantation of myxoid dedifferentiated Chondrosarcoma at donor site. Asian J Oncol 2018;4:17-20

8. Sacco AG, Cohen EE: Current treatment options of recurrent and metastatic hean and neck squamous cell carcinoma. Jour of Clinical Oncol 2015 , Vol 33

9. Brockstein B, Haraf DJ, Rademaker AW, Kies MS, Stenson KM, Rosen F, Mittal BB, Pelzer H, Fung BB, Witt ME, et al. Patterns of failure, prognostic factors and survival in locoregionally advanced head and neck cancer treated with concomitant chemoradiotherapy: a 9-year, 337-patient, multi-institutional experience. Ann Oncol 2004; 15:1179

10. Brockstein BE. Management of recurrent head and neck cancer: recent progress and future directions. Drugs 2011; 71:1551-9

11. Bansal R, Patel TS, Bhullar C, Patel SM, Sarin J. Metastases to the donor site of the pectoralis major myocutaneous flap following reconstructive surgery: a rare complication. Plastic and reconstructive surgery. 2004 Dec 1;114(7):1965-6.

12. Kartikeyan S, Shukla M, Pandey M. Donor site metastasis after pectoralis major myocutaneous flap reconstruction for oral squamous cell carcinoma. Otolaryngology-Head and Neck Surgery. 2009 Nov;141(5):657-8.

13. Reddy V, Vijayakumar M, Chris Deepak A, Mahesh K, Jagadish S. Pectoralis major myocutaneous (PMMC) flap donor site recurrence in a case of buccal mucosal cancer: a case report.

14. Kain R, Dash S. Tumor Recurrence at Donor Site of Pectoralis Major Myocutaneous Flap with Tumor-free Primary Oral Carcinoma. The Gulf journal of oncology. 2018 Jan 1;1(26):64-6.

\section{Tables}


Table 1

- Oral cavity squamous cell carcinoma cases with recurrence at PMMC flap donor site

\begin{tabular}{|c|c|c|c|c|c|c|c|c|c|c|c|c|}
\hline Author & Year & $\begin{array}{l}\text { Age at } \\
\text { presentation }\end{array}$ & Sex & $\begin{array}{l}\text { Index } \\
\text { lesion } \\
\text { site }\end{array}$ & $\begin{array}{l}\text { Index } \\
\text { lesion } \\
\text { type }\end{array}$ & $\begin{array}{l}\text { Index } \\
\text { lesion } \\
\text { stage }\end{array}$ & $\begin{array}{l}\text { Initial } \\
\text { treatment }\end{array}$ & $\begin{array}{l}\text { Recurrence } \\
\text { at the } \\
\text { primary } \\
\text { site }\end{array}$ & $\begin{array}{l}\text { Site of } \\
\text { recurrence }\end{array}$ & $\begin{array}{l}\text { Duration } \\
\text { to } \\
\text { recurrence }\end{array}$ & Management & C \\
\hline $\begin{array}{l}\text { Bansal et } \\
\text { al }^{11}\end{array}$ & 1965 & 45 & M & $\begin{array}{l}\text { Left } \\
\text { lower } \\
\text { alveolus }\end{array}$ & SCC & $\begin{array}{l}\text { Stage } \\
\text { III }\end{array}$ & $\begin{array}{l}\text { Surgery with } \\
\text { adjuvant } \\
\text { radiation }\end{array}$ & No & $\begin{array}{l}\text { PMMC } \\
\text { donor site }\end{array}$ & 2 months & NA & $\Lambda$ \\
\hline $\begin{array}{l}\text { Badellino et } \\
\mathrm{al}^{4}\end{array}$ & 1988 & 37 & $M$ & $\begin{array}{l}\text { Floor of } \\
\text { Mouth }\end{array}$ & $\begin{array}{l}\text { Grade } \\
2 \\
\text { SCC }\end{array}$ & T4N1 & $\begin{array}{l}\text { BL MRND, } \\
\text { Adjuvant RT } \\
\text { and Adjuvant } \\
\text { CT } \\
\text { (Vinblastine, } \\
\text { Bleomycin } \\
\text { and } \\
\text { Methotrexate, } \\
4 \text { courses) } \\
\text { f/b } \\
\text { composite } \\
\text { resection of } \\
\text { primary site }\end{array}$ & Yes & $\begin{array}{l}\text { PMMC } \\
\text { flap } \\
\text { vascular } \\
\text { pedicle } \\
\text { base }\end{array}$ & 8 months & Palliative RT & $\begin{array}{l}{[} \\
\mathrm{n}\end{array}$ \\
\hline $\begin{array}{l}\text { M Jog et } \\
\mathrm{al}^{5}\end{array}$ & 2001 & 53 & $M$ & $\begin{array}{l}\text { Right } \\
\text { Tonsil } \\
\text { with } \\
\text { right } \\
\text { RMT } \\
\text { extention }\end{array}$ & SCC & T3N1 & $\begin{array}{l}\text { Surgery, } \\
\text { Adjuvant RT }\end{array}$ & No & $\begin{array}{l}\text { PMMC } \\
\text { Donor site }\end{array}$ & 1 year & $\begin{array}{l}\text { Surgery } \\
\text { Excision of } \\
\text { tumour with } \\
\text { anterior chest } \\
\text { wall and } \\
\text { modified } \\
\text { deltopectoral } \\
\text { flap } \\
\text { reconstruction } \\
\text { f/b RT to } \\
\text { anterior chest } \\
\text { wall }\end{array}$ & $\begin{array}{l}c \\
b \\
u \\
\text { t }\end{array}$ \\
\hline $\begin{array}{l}\text { M Jog et } \\
\mathrm{al}^{5}\end{array}$ & 2001 & 61 & $M$ & $\begin{array}{l}\text { Oral } \\
\text { tongue } \\
\text { and } \\
\text { tongue } \\
\text { base }\end{array}$ & SCC & T3N1 & $\begin{array}{l}\text { Surgery, } \\
\text { Adjuvant RT }\end{array}$ & No & $\begin{array}{l}\text { PMMC } \\
\text { vascular } \\
\text { pedicle } \\
\text { base }\end{array}$ & 8 months & Local RT & $\begin{array}{l}\mathrm{c} \\
\mathrm{n} \\
\mathrm{o} \\
\mathrm{e}\end{array}$ \\
\hline $\begin{array}{l}\text { Senniappan } \\
\text { Kartikeyan } \\
\text { et al }^{12}\end{array}$ & 2009 & 35 & $\mathrm{~F}$ & $\begin{array}{l}\text { Oral } \\
\text { tongue }\end{array}$ & $\begin{array}{l}\text { Grade } \\
2 \\
\text { SCC }\end{array}$ & & $\begin{array}{l}\text { Surgery, } \\
\text { Adjuvant RT }\end{array}$ & Yes & $\begin{array}{l}\text { PMMC } \\
\text { flap } \\
\text { vascular } \\
\text { pedicle } \\
\text { base }\end{array}$ & 6 months & $\begin{array}{l}\text { Patient } \\
\text { refused } \\
\text { surgery. } \\
\text { Palliative oral } \\
\text { methotrexate }\end{array}$ & $\Lambda$ \\
\hline $\begin{array}{l}\text { Vasu Reddy } \\
\text { C et al }\end{array}$ & 2012 & 35 & $M$ & $\begin{array}{l}\text { Right } \\
\text { Buccal } \\
\text { Mucosa }\end{array}$ & $\begin{array}{l}\text { Grade } \\
2 \\
\text { SCC }\end{array}$ & NA & $\begin{array}{l}\text { One cycle CT } \\
\text { (Cisplatin, } \\
\text { 5FU) f/b } \\
\text { surgery, } \\
\text { Adjuvant RT }\end{array}$ & No & $\begin{array}{l}\text { PMMC } \\
\text { donor site } \\
\text { and Right } \\
\text { temporal } \\
\text { area }\end{array}$ & 2 months & $\begin{array}{l}\text { Concurrent } \\
\text { CTRT }\end{array}$ & $\Lambda$ \\
\hline Kain et al ${ }^{14}$ & 2018 & 50 & $M$ & $\begin{array}{l}\text { Right } \\
\text { Alveolus } \\
\text { SCC }\end{array}$ & $\begin{array}{l}\text { Grade } \\
2 \\
\text { SCC }\end{array}$ & T2NO & $\begin{array}{l}\text { Surgery with } \\
\text { Adjuvant RT }\end{array}$ & No & $\begin{array}{l}\text { PMMC } \\
\text { flap } \\
\text { muscle }\end{array}$ & 3 months & Excision & $\mathrm{F}$ \\
\hline
\end{tabular}

\section{Figures}




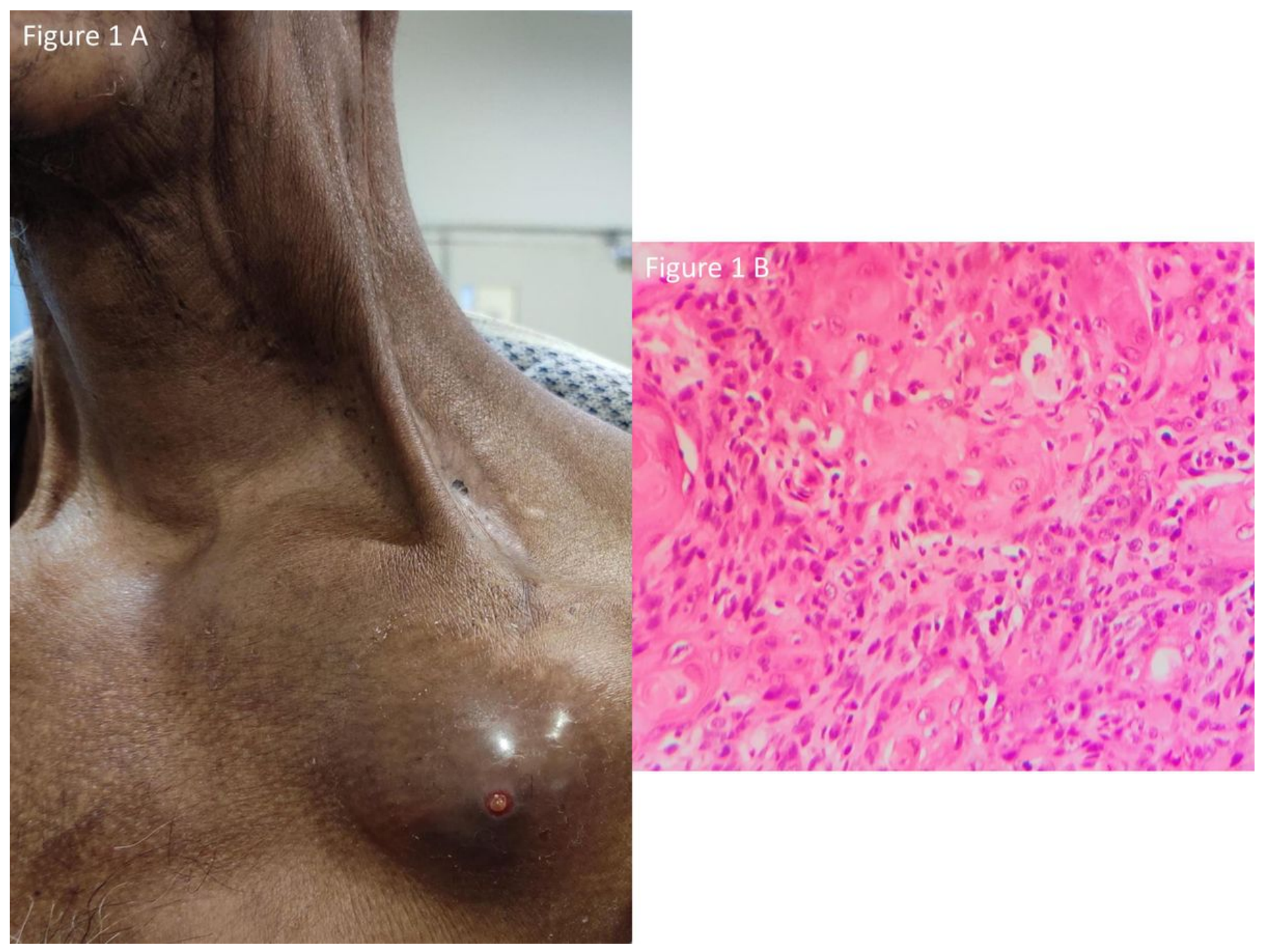

Figure 1

A - Clinical picture at presentation. B - Histopathological picture 40x. 


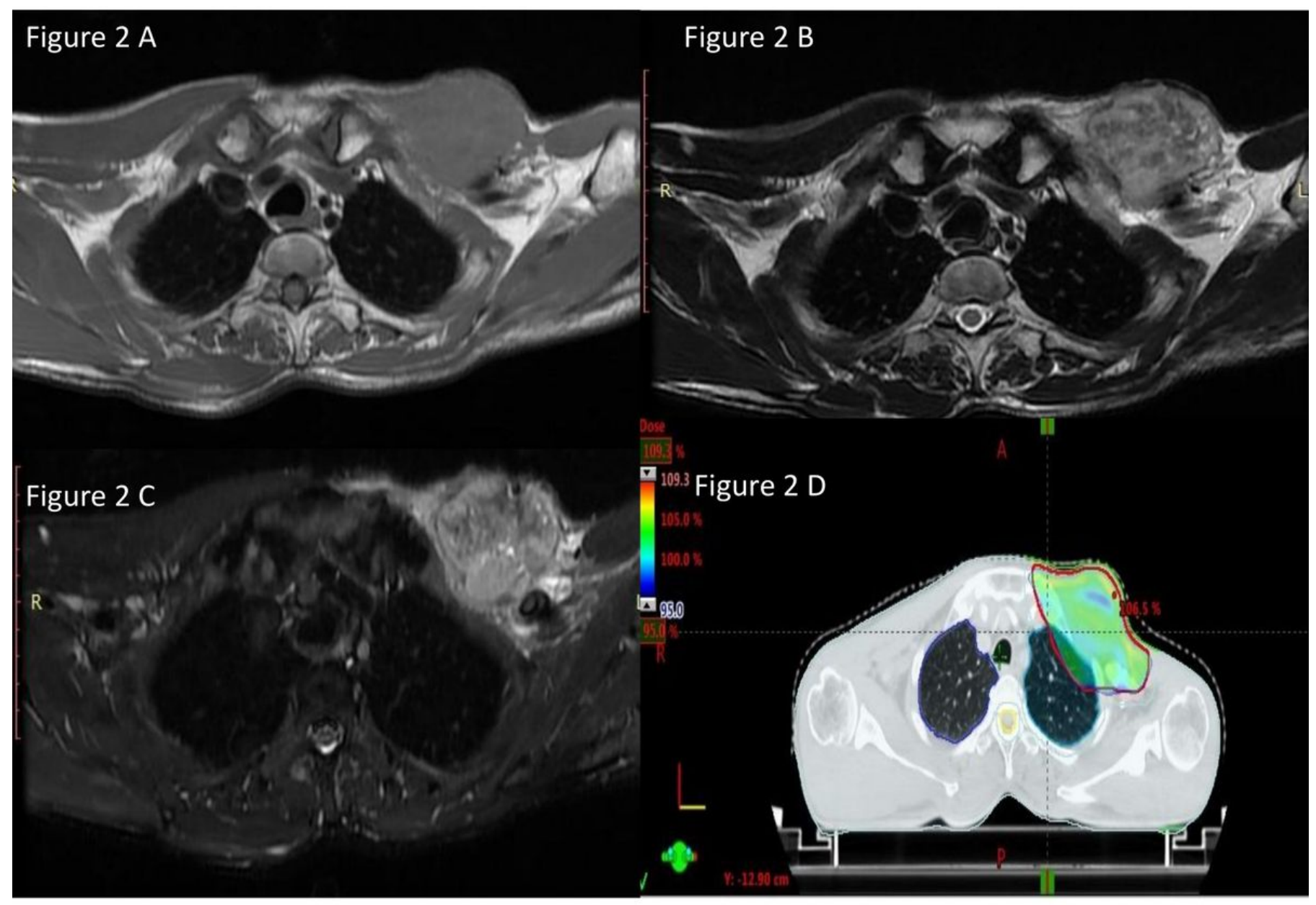

Figure 2

A - Pre CTRT MRI T1W Axial. B - Pre CTRT MRI T2W Axial. C - Pre CTRT MRI STIR Axial. D - IMRT Plan Axial. 


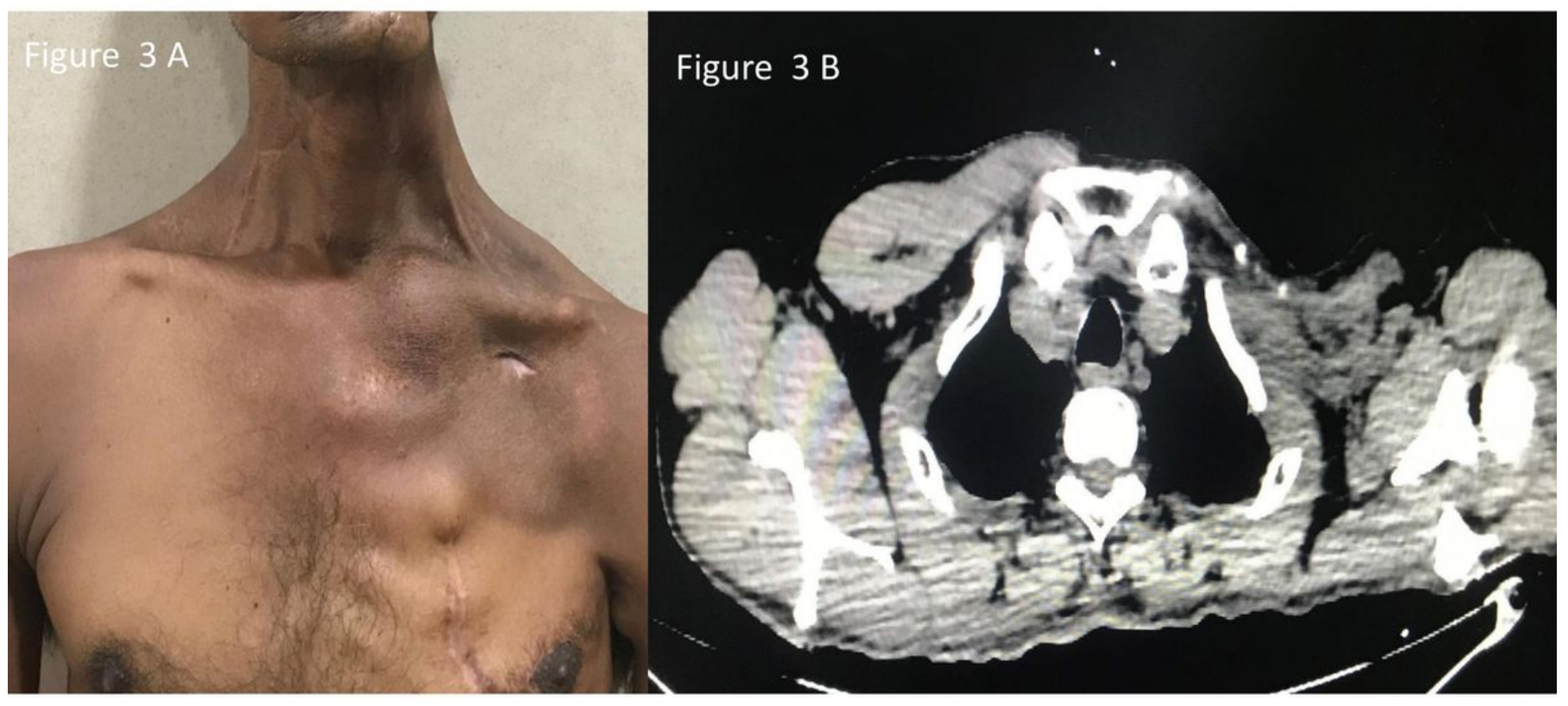

Figure 3

A - Post CTRT Clinical photograph at follow up. B - Post CTRT CT scan Axial. 